\title{
A Comparative Study of the Perceptions of Accounting Educators and Accountants on Skills Required of Accounting Education Graduates in Automated Offices
}

\author{
Nwokike, Felicia Ogonnia ${ }^{1, *} \&$ Eya, Gloria Mgboyibo ${ }^{1}$ \\ ${ }^{1}$ Department of Technology and Vocational Education, Enugu State University of Science and Technology (ESUT), \\ Nigeria \\ *Correspondence: Department of Technology and Vocational Education, Enugu State University of Science and \\ Technology (ESUT), Nigeria. Tel: 234-806-841-1098. E-mail: Ogonnianwokike@Yahoo.Com
}

Received: July 17, 2015

Accepted: September 18, $2015 \quad$ Online Published: October 7, 2015

doi:10.5430/wje.v5n5p64

URL: http://dx.doi.org/10.5430/wje.v5n5p64

\begin{abstract}
The study dealt with perception of accounting educators and senioraccountants on skills required of accounting education graduates for effective job performance in automated offices. The study adopted a descriptive researchdesign.The population consisted of 149 respondents, made up of 80 accounting educatorsin public tertiary institutionsand 69 senioraccountants in government ministries in Enugu metropolis of Enugu State, Nigeria. The entire population was used for the study and no sample was drawn. Two research questions and two hypotheses guided the study. The instrument used for data collection was a structured questionnaire developed by the researcher. The instrument was validated by three experts. A 32 item questionnaire was used for data collection. The data collected were analyzed using mean and standard deviation while t-test was used to test the hypothesesat 0.05 level of significance. The findings of the study revealed that accounting education graduates requiretechnology skills such as computer operations skill, word processing soft ware, spreadsheet software etcand_soft skills such as ability to analyze and interpret financial data, interact with diverse groups; Listen actively to one's boss etc for effective job performance in automated offices. The study concluded that Technology and soft skills are required by accounting education graduates for effective job performance in automated offices. It was recommended among others that technology and soft skills should be an integral part of accounting education curriculum.
\end{abstract}

Keywords: automated office; technology skills; soft skills; $21^{\text {st }}$ century skills and accounting education graduates

\section{Introduction}

In recent time, many small and large officesare characterized by automation. Nwokike (2015) observed that virtually every modern office of today is characterized by automation with computer as the major information and communication technology equipment. There is hardly any office one will visit today in public or private sectors that has nocomputers. In other words, modern offices of today arehighly mechanized. Business and office environment are changing very fast at unimaginable rate as a result of technological innovations. Obayi and Okwuanaso (2003) opine that business and offices are changing very fast and with unexpected speed and dimensions. Apart from the technical know-how of one's profession, there are two set of skills that every employer of labour today's is looking for in an employee; the technology skills and soft skills.

Technology skills are such skills like computer operations, data base, accounting software and spread sheet etc. Turner (2005) noted that as computer and associated technologies continued to change and evolved, educators must continue to strive for excellence in their work. Turner identified some basic technology skills that all educators should have as, word processing skills, spread sheet, database, electronic presentation, web navigation, web site, design, e-mail management skills, digital cameras, computer networking knowledge, file management and windows explorer and downloading software from the web etc.

This entails that educators should devote their time and effort to maintain and improve their technology skills. These skills facilitate practical skills that are needed in many occupations. 
In the same vein, soft skills also known as people's skill are personal attributes of an individual. Soft skills describe anindividual's ability to interact with others. According to Rousa (2014), soft skills are personal attributes that enhance an individual's interactions, career prospects and job performance. Rousa stress that soft skills enables an individual to get a job and keep it. In the viewof Perreault (2004), soft skills relate to the way individuals interact with each other. They include; leadership abilities, team player skills, commutation ability and motivating team members.

Recently, the American Institute of Certified Public Accountants (AICPA) vision 2011 project described soft skills as a core competency that all accountants should possess. Soft skills identified by AICPA included strategic, critical thinking, communication and leadership skills. Low, Samkin and Liu (2013) opine that accountants today are expected to be able to link data knowledge, provide quality advice for strategic decision making, give and enhance information with meaningful context as well as influence and motivate others. The American management Co-operation in Kay and Janet (2012) indicate that employers want workers who can think critically, solve problems creatively, innovate, collaborate and communicated effectively in the office. The soft skills are used synonymously with $21^{\text {st }}$ century skills. Edglossary Organization (2014) describe $21^{\text {st }}$ century skills as a broad set of knowledge, skills, work habits and character traits that are believed by educators, school reformers, university professors and employers to be critically important to success in work place. Some of the $21^{\text {st }}$ century skills identified by Edglossary organization includes: critical thinking, problem solving, reasoning, analysis interpretation, creativity, and oral and written communication, team, work information and communication technology, etc. Institute of Museum and Library Services Project Team and Task Force (2014) considered the list of skills commonly referred to soft skills as critical thinking and problem solving, creativity and innovation communication, collaboration and visual literacy etc.

Accounting education students require the soft skills in order to succeed in the information age. Rotherham\&Willinghan( 2009) remark that a growing number of business leaders, politicians and educators agreed that student need $21^{\text {st }}$ century skills to be successful today. They note that it is exciting to believe that people live in times that are so revolutionary that they demand new and different activities. They also identified critical thinking and problem solving skills as components of human progress throughout history as an example of $21^{\text {st }}$ century skills.

In another development, Fouche (2006) note that lack of skills on the part of the learners is one of the factors affecting accounting education. Accounting education offers the graduates specialized skills in accounting such as financial accounting, cost accounting, management accounting, taxation, auditing and investigation and public sector accounting (Tumar, 2009). Accounting education is that aspect of education that deals with recording and maintaining of books of account. Accounting education has the potential of improving the way people record their different business transactions. It is also helpful for determination of tax. It is impossible for business to thrive without accounting data and effective use of them for business planning. This is in agreement with Nweze (2015) who noted that accounting is the universal language of business. The main objective of accounting education is to provide students with an advanced, clearly and usable level of accounting knowledge and skills. The students who acquired the theoretical knowledge, practical skills and work attitudes in business education with emphasis in accounting in the University are regarded as accounting education graduates.

The framework for international education standards for professional accountants (2009) published by International Accounting Education Standard Board (IAESB) stated that the main objective of accounting education is to develop competent professional accountants who possess the necessary professional knowledge, skills, values,ethics and attitudes in accounting profession. Davidson, Slotrick and Waldman (2000) noted that accounting and auditing firms have called for changes in accounting education that would make new accountants more capable of meeting the challenges of the modern day working environment.

The modern day working environment is characterized by automation. The modern office of today where accounting education graduates are going to work is highly automated. Agomuo(2014) describe office automation as a phenomenon in office information handling where operations undergo systematic sequences that are electrically-driven and without human interaction from input to output. According to Osuala(1998) automation implies that machines are used to perform routine office functions formerly done by people. Osuala further noted that automation applies to office activities such as accounting, mail handling and filing. In the view of Nte(1996) in Obayi and Okwuanaso (2003) office mechanization or automation refer to the adaptation of technology to office activities. Office automation does not just mean office mechanization but also the conversion of information as well. Basic activities of office information include storage of information, data exchange and data management. With office automation, many tasks are accomplished faster, enhances quality work with greater speed and accuracy and multiple people can update data in the event of changes. Technology innovations are greatly affecting the traditional 
accounting firms and these firms are implementing new electronic system for submitting and preparing financial records, inventory information, preparation of wages and salaries and other vital business information.

Many employers believe that education is failing in its role to adequately develop needed skills in students. (American Management Association 2010 survey in Kay and Janet 2012). It is against this backdrop that an attempt was made to determine the perception of accounting educators in public tertiary institutions and senior accountants employed in public ministries in Enugu metropolis of Enugu State on technology and soft skills required of accounting education graduates for effective job performance in an automated offices.

The development of the needed skills in accounting education graduates is a panacea for their effective work performance in an automated office. Automated or electronic offices are being used today instead of the orthodox method of pen and paper. Research findings showed that accounting education graduates were lacking certain skills when entering the workplace especially in this era of information and communication technology. If accounting graduates were not fortified with these skills, especially technology and soft skills, they may likely perform below expectation especially in this highly competitive world characterized by globalization and mechanization.

\section{Purpose of the Study}

The main purpose of the study was to determine the skill required by accounting education graduates for effective job performance in automated offices. Specifically, the study sought to:

1. determine the technology skills required by accounting education graduates for effective job performance in an automated offices in Enugu metropolis of Enugu State of Nigeria and

2. determine the soft skills required by accounting education graduates for effective job performance in an automated office in Enugu metropolis of Enugu State of Nigeria.

\section{Research Questions}

The following research question were answered by the study

1. What are the technology skills required by accounting education graduates for effective job performance in an automated offices in Enugu metropolis of Enugu State of Nigeria.

2. What are soft skills required by accounting education gradates for effective job performance in an automated offices in Enugu metropolis of Enugu State of Nigeria.

\section{Hypotheses}

The following hypotheses were tested at 0.05 level of significance:

1. There is no significant difference in the mean ratings of accounting educators and accountants on technology skills required by accounting education graduates for effective work performance in automated offices.

2. There is no significant difference in the mean ratings of accounting educators and accountants on soft skills required by accounting education graduates for effective work performance in automated offices.

\section{Method}

The study adopted a descriptive research design to determine the perception of accounting educators and accountants on skills required by accounting education graduates for effective job performance in automated offices in Enugu State. The study was carried out in Enugu metropolis of Enugu State of Nigeria. The population consisted of 149 respondents made up of 80 accounting educators in public tertiary institutions and 69 senior accountants in government ministries in Enugu metropolis, Enugu State of Nigeria. Due to the manageable size of the population, the entire population was used. The instrument used for data collection was a structured questionnaire titled perception of accounting educators and accountants on skills required by accounting education graduates by accounting education graduates (PSAAE) developed by the researcher. A 32 item questionnaire was used for data collection. Each questionnaire had four point scale of very highly required (4) highly required (3), moderately required (2) and not required (1). The instrument used for data collection was validated by three experts. Two experts were from the Department of Technology and Vocational education of Enugu State University of Science and Technology and one expert from government ministries in Enugu State. Data collected in respect of the study was 
analyzed using mean and standard deviation for the research questions while t-test was used for testing the hypotheses at 0.05 level of significance. For decision to be reached regarding the mean, the upper and lower limits of the mean were used as basis for decision: very highly required (VHR) 3.50-4.00 highly required (HR) 2.50-3.49, moderately required (MR) 1.50-2.49 not required (NR) 1.00-1.49. The t-test was used to test the hypotheses at 0.05 level of significance. The null hypothesis was rejected if the $\mathrm{t}$-calculated value was more than the critical or $\mathrm{t}$ - table value: but when the t- calculated was less than the critical t-table, the null hypothesis was not rejected.

\section{Results}

The results are presented in tables $1-4$ in line with the research questions and hypotheses of the study.

\section{Research question 1}

What are the technology skills required by accounting education graduates for effective job performance in an automated offices in Enugu metropolis of Enugu State.

The information contained in Table 1 revealed that out of 18 items on technology skills required by accounting education graduates for effective job performance in an automated office, 6 items are rated very highly required, 10 items are rated highly required whereas 2 items are rated moderately required. The items that are very highly required are item 1, 5, 8, 15, 16 and 17 while items rated highly required are item 2, 4 6, 7, 9, 11, 13, 14 and 18 and item rated moderately required are item 3 , and 10 . The standard deviation of the two groups which ranges from 0.40 -0.88 indicated that the respondents are very close in their ratings.

Table 1. Mean Ratings of the Accounting Educators and Accountants on the Technology Skills Required by Accounting Education Graduates for Effective Job Performance in an Automated Office in Enugu State

\begin{tabular}{lllllllll}
\hline S/N & Technology skills & $\dot{\mathbf{x}}_{\mathbf{1}}$ & $\mathbf{S D}_{\mathbf{1}}$ & $\dot{\mathbf{x}}_{\mathbf{2}}$ & $\mathbf{S D}_{\mathbf{2}}$ & $\overrightarrow{\mathbf{x}} \mathbf{t}$ & $\mathbf{S D t}$ & $\mathbf{R M K}$ \\
\hline 1 & Computer operations skills & 3.80 & 0.40 & 3.80 & 0.39 & 3.80 & 0.40 & $\mathrm{VHR}$ \\
2 & Accounting software & 3.47 & 0.67 & 3.49 & 0.65 & 3.48 & 0.66 & $\mathrm{HR}$ \\
3 & Programming languages & 2.27 & 0.85 & 2.24 & 0.86 & 2.25 & 0.86 & $\mathrm{MR}$ \\
4 & World wide web & 3.01 & 0.81 & 3.04 & 0.81 & 3.03 & 0.81 & $\mathrm{HR}$ \\
5 & Word processing software & 3.51 & 0.65 & 3.52 & 0.65 & 3.52 & 0.65 & $\mathrm{VHR}$ \\
6 & Data base software & 3.31 & 0.88 & 3.30 & 0.87 & 3.31 & 0.88 & $\mathrm{HR}$ \\
7 & Window software & 3.17 & 0.67 & 3.17 & 0.66 & 3.17 & 0.66 & $\mathrm{HR}$ \\
8 & Spread sheet software & 3.65 & 0.57 & 3.68 & 0.52 & 3.67 & 0.55 & VHR \\
9 & Graphic software (Adobe) & 2.80 & 0.71 & 2.84 & 0.71 & 2.82 & 0.71 & $\mathrm{HR}$ \\
10 & System analysis and design & 2.46 & 0.96 & 2.52 & 0.94 & 2.49 & 0.95 & $\mathrm{MR}$ \\
11 & File directory management & 2.95 & 0.57 & 2.97 & 0.56 & 2.96 & 0.57 & $\mathrm{HR}$ \\
12 & E-business & 3.00 & 0.57 & 3.02 & 0.56 & 3.01 & 0.57 & $\mathrm{HR}$ \\
13 & Intranet and extranet & 3.00 & 0.57 & 3.05 & 0.56 & 3.03 & 0.57 & $\mathrm{HR}$ \\
14 & Presentation software & 2.68 & 0.89 & 2.72 & 0.90 & 2.70 & 0.90 & $\mathrm{HR}$ \\
15 & Computer hardware & 3.52 & 0.77 & 3.55 & 0.75 & 3.53 & 0.76 & VH \\
16 & Communication software & 3.55 & 0.74 & 3.56 & 0.73 & 3.56 & 0.73 & VHR \\
17 & Technology management and handling & 3.55 & 0.74 & 3.56 & 0.73 & 3.56 & 0.74 & VHR \\
18 & Management information & 3.42 & 0.74 & 3.44 & 0.73 & 3.43 & 0.73 & $\mathrm{HR}$ \\
& GRAND MEAN & & & & & $\mathbf{3 . 1 8}$ & $\mathbf{0 . 6 6}$ & \\
\hline
\end{tabular}

End note

$X_{1}^{\prime}=$ Mean of accounting educators

$\mathrm{X}_{2}=$ Mean of Senior Accountants

$\mathrm{SD}_{1}=$ Standard deviation of accounting educators

$\mathrm{SD}_{2}=$ Standard deviation of senior accountants

$\mathrm{X}_{\mathrm{t}}=$ Average mean of all the respondents

$\mathrm{SD}_{\mathrm{t}}=$ Average standard deviation of all the respondents 


\section{Research question 2}

What are the soft skills required by accounting education graduates for effective job performance in an automated office.

The analysis of the result in table 2 revealed that out of 14 items on soft skills required by accounting education graduates for effective job performance in automated offices, four items are rated very highly required while nine items are rated highly required. They are items 1,2,6,7 and 10 and items 3, 4, 5,8,10,11,12,13, and 14 respectively. The standard deviation of the two groups showed that they are very close intheir ratings. Hence, accounting educators and accountants perceive soft skills as required by accounting education graduates for effective job performance in automated offices in Enugu metropolis of Enugu State.

Table 2. Mean Ratings of Accounting Educators and Senior Accountants on Soft Skills Required by Accounting Education Graduates for Effective Job Performance in an Automated Office in Enugu State

\begin{tabular}{lllllllll}
\hline S/N & Soft skills: Abilities to: & $\overline{\mathbf{x}}_{\mathbf{1}}$ & $\mathbf{S D}_{\mathbf{1}}$ & $\overline{\mathbf{x}}_{\mathbf{2}}$ & $\mathbf{S D}_{\mathbf{2}}$ & $\overline{\mathbf{x}} \mathbf{t}$ & $\mathbf{S D t}$ & $\mathbf{R M K}$ \\
\hline 1 & Analyze and interpret financial data & 3.80 & 0.50 & 3.50 & 0.50 & 3.50 & 0.50 & VHR \\
2 & Adapt to change & 3.48 & 0.50 & 3.50 & 0.50 & 3.49 & 0.50 & $\mathrm{HR}$ \\
3 & Develop ideas that are unique & 3.16 & 0.68 & 3.18 & 0.69 & 3.17 & 0.69 & $\mathrm{HR}$ \\
4 & Communicate both formally and informally & 3.36 & 0.73 & 3.31 & 0.75 & 3.33 & 0.74 & $\mathrm{HR}$ \\
5 & Work with other in groups & 3.48 & 0.77 & 3.50 & 0.75 & 3.49 & 0.76 & $\mathrm{HR}$ \\
6 & Interact with diverse groups & 3.82 & 0.38 & 3.85 & 0.35 & 3.83 & 0.37 & VHR \\
7 & Listen actively to ones boss & 3.50 & 0.76 & 3.49 & 0.77 & 3.49 & 0.38 & VHR \\
8 & Create rapport with others & 2.83 & 0.37 & 2.82 & 0.38 & 2.83 & 0.38 & $\mathrm{HR}$ \\
9 & Be eager and willing to learn & 3.50 & 0.50 & 3.50 & 0.50 & 3.50 & 0.50 & VHR \\
10 & Define and communicate vision ideas & 3.48 & 0.77 & 3.50 & 0.75 & 3.49 & 0.76 & $\mathrm{HR}$ \\
11 & Ask question & 3.16 & 0.37 & 3.17 & 0.38 & 3.17 & 0.38 & $\mathrm{HR}$ \\
12 & Venture into risk & 3.17 & 0.68 & 3.18 & 0.67 & 3.18 & 0.69 & $\mathrm{HR}$ \\
13 & Make accurate decision making & 3.33 & 0.47 & 3.33 & 0.47 & 3.33 & 0.47 & $\mathrm{HR}$ \\
14 & Manage time effectively & 3.33 & 0.47 & 3.33 & 0.47 & 3.33 & 0.47 & $\mathrm{HR}$ \\
& GRAND MEAN & & & & & $\mathbf{3 . 3 6}$ & $\mathbf{0 . 5 4}$ & \\
\hline
\end{tabular}

\section{Hypotheses}

$\mathrm{Ho}_{\mathrm{i}}$ : There is no significant difference in the mean ratingsof accounting educators and senior accountants on the technology skills required by accounting education graduates for effective job performance in automated office.

Table 3 shows that items on technology skills required by accounting education graduates have t-value of0.18 which is less than the table value of 1.96 at 0.05 level of significance. This shows that there is no significant difference in the mean ratings of accounting educators and senior accountants on technology skills required by accounting education graduates for effective job performance in automated offices in Enugu metropolis of Enugu State.

Table 3. Summary of t-test Result of the Mean Ratings of Accounting Educators and Senior Accountants on Technology Skills Required by Accounting Education Graduates

\begin{tabular}{llllllll}
\hline Variable & $\mathbf{N}$ & $\overline{\mathbf{x}}$ & SD & DF & t-cal & t-crit. & Rmk \\
\hline Accounting educators & 80 & 3.17 & 0.70 & & & & Do not \\
Senior Accountants & 69 & 3.19 & 0.69 & 14.7 & 0.18 & 1.96 & Reject \\
\hline
\end{tabular}

$\mathrm{HO}_{2}$ : There is no significant difference in the mean ratings of accounting educators andsenior accountants on soft skills required by accounting education graduates for effective job performance in automated offices in Enugu metropolis of Enugu State.

Table 4 shows that items on soft skill have a calculated t-value of 0.00 which is less than the table value of 1.96 at 0.05 level of significance. This is an indication that there was no significant difference in the mean ratings of accounting educators and senior accountants on the soft skills required of accounting education graduates for effective work performance in an automated office in Enugu metropolis of Enugu State. 
Table 4. Summary of t-test Result of Mean Ratings of Accounting Educators and Senior Accountants on Soft Skills Required by Accounting Education Graduates for Effective Job Performance in Enugu Metropolis

\begin{tabular}{lllllll}
\hline Variable & $\mathbf{N}$ & $\overline{\mathbf{x}}$ & SD & DF & t-cal & t-crit. \\
\hline Accounting educators & 80 & 3.36 & 0.53 & 14.7 & 0.00 & 1.96 \\
Senior Accountants & 69 & 3.36 & 0.56 & & & \\
\hline
\end{tabular}

\section{Discussion}

Regarding research question one, result showed that computer operation skill is very highly required of accounting education graduates for effective work performance in automated offices in Enugu metropolis.Onwuachu (2013) identified the basic computer skills such as knowing how to power the computer, being able to use mouse to interact with elements on the screen, being able to use the computer keyboard, ability to possess functional knowledge of word processing, know how to use e-mail and internet etc. Atakpa (2006) noted that modern business offices were rapidly changing as a result of office automation which brought about new methods of carrying out functions performed by office workers. The study revealed that apart from the computer operation skill, all the technology skills were required by accounting education graduates. Therefore, any accounting graduate who lacked the technology skill might not be relevant in electronic / automated offices in this $21^{\text {st }}$ century and beyond. The finding corroborates with the view of Osuala, (2004) who observed that in order to prepare business students for the present and future, attempt should be made to incorporate technological development in the Nigerian schools because the school environment of the $22^{\text {nd }}$ century would be centers of electronic marvels. Osuala stressed that the incorporation of technological developments into Nigerian school system will have a rapid effect upon the technological revolution expected in business and economic environment. Further, Nwokike (2015) opined that a gap might likely exist between the skill acquired and the ones needed in the field of work. The gap need to be closed by accountancy educators by integrating these technology skills in teaching/learning of accounting education with the view of preparing the children for an effective job performance in electronic offices. The findings of this study collaborateswith offordile (2011) who found that among the necessary pre - requisite for advancement in business education was the need to equip students with - up- to date skills, otherwise known as $21^{\text {st }}$ century skills.

The test of hypothesis one $\left(\mathrm{Ho}_{1}\right)$ showed that significant difference did not exist in the mean ratings of accounting educators and senior accountants on the technology skills required by accounting education graduates for effective work performance in automated offices in Enugu metropolis. This signified that both accounting educators and senior accountants perceived technology skills as required by accounting education graduates for effective job performance in automated offices in Enugu metropolis of Enugu State.

Result of research question two on soft skills required of accounting education graduates revealed that soft skills werehighly required by accounting education graduates for effective job performance in an automated offices. The finding of this study was related to that of LowSamkin and Liu (2013) which found that the business world has witnessed dramatic changes due to technology, business complexity and globalization. As a result, accountant needs to master not only the technical skills of their job but also various soft skills. Low, Samkin and Liu (2013) citing Mohamumed and Lashired opine that the demand for such skills and competencies has caused changes in accounting education, providing both technical skills and soft skill to accounting students in order to prepare them for the business world in the $21^{\text {st }}$ century. An organization' success rests largely on the soft skills of its people, that is, their ability to develop strong relationship with their customers. Though Low, Samkin and Liu (2013) indicated that educators could not fully prepare accounting students with all necessary soft skills required to face them in both their professional and personal likes but can enhance the students' ability to acquire the soft skill.

Result of hypothesis two $\left(\mathrm{Ho}_{2}\right)$ showed that there was no significant difference in the mean ratings of accounting educators and senior accountants on soft skills required by accounting education graduates for effective job performance in an automated offices in Enugu metropolis of Enugu State. They concurred that soft skills were required of accounting education graduates for effective job performance in automated offices in Enugu metropolis of Enugu State.

\section{Conclusion}

Technology has reshaped the way basic office functions such as receiving, recording and giving information are performed and also today, many firms are utilizing office automation. Based on the data analyzed and findings made, the study concluded that technology and soft skills are required by accounting education graduates and they are panacea for effective job performance in automated/electronic offices. 


\section{Recommendations}

Based on the findings of the study, the following recommendations were made;

1. The government need to provide relevant technology facilities in institutions for developing the technology skills of accounting education graduates.

2. Accounting educators should strive to enhance the soft skill of the accounting education students.

3. Technology and soft skill identified by this study should be an integral part of accounting education curriculum.

4. School industry collaboration should be enhanced for developing the soft skills of accounting education students.

\section{References}

Akakpa, R.A.C. (2013). New Technologies in Business education applied to office information system skills used by secretaries in the electronic office. Association of business educators of Nigeria Book of readings, 83-89.

American Institute of Certified Public Accountants (2011). The CPA vision project and beyond. Retrieved 12t $\mathrm{t}^{\mathrm{h}}$ April, 2015 from http://www.aicpa.org

Andrew, J.R., \& Daniel W. (2009). Teaching for the $21^{\text {st }}$ century skills: The challenge ahead. Educational leadership, 67(1), 16-21.

Davidson, R.A, Slotrick, S.A., \& Waldman, D.A. (2006). Using linguistic performance. Accounting education, 9(1), 53-66. http://dx.doi.org/10.1080/096392800413654

Edglossary Organization (2014). $21^{\text {st }}$ century skills- The Glossary of Education Reform. Retrieved $30^{\text {th }}$ March, 2015 from edglossary.Org $/ 21^{\text {st }}$ century-skills/

Fouche, J.P. (2013). A renewed call for change in accounting education practice. International Journal of Education practice, $5(2), 137-150$.

Kay, A.H., \& Janet, L.L. (2012). Employment skills for $21^{\text {st }}$ century. Retrieved from scholar lib. It edu/hodge. Html. $21^{\text {st }}$

Kumar, V. (2009). Accounting education. Retrieved $31^{\text {st }}$ March, 2015 from www.SvtuitionOrg/2009/02/accounting

Low, M., Samkin, G., \& Liu, C. (2013). Accounting education and the provision of soft skill: implication of the recent Netherland academic requirements changes. e-Journal of business education and scholarship of teaching, $7(1), 1-33$.

Nweze, A.U. (2015). Accounting: A universal business language. Enugu: cecta, Nig.

Nwokike, F.O. (2014). Improving the entrepreneurial competencies of business education students in universities in the south East and South South states of Nigeria for self employment. An unpublished Ph.Dthesis: Enugu State University of science and Technology, Nigeria.

Nwokike, F.O. (2015). Integration of new technologies in teaching and learning of accounting in public tertiary institution: A critical role of an accountancy educator. International Journal of Scientific Research in Education, $8(1), 29-36$.

Obayi. T.U., \& Okwuanaso, S.I. (2003). Elements of office automation. Enugu: JTC publisher.

Onwuachu, R.N. (2013). Achieving quality in teaching/learning business education in colleges of educatin through the use of information and communication technology (ICT) skill. Association of business educators of Nigeria.Book of readings, 3(1), 171-175.

Osuala, E.C. (2014). Business and computer education. Enugu: Cheston Agency.

Osuala, E.C. (1998). Automation and its impact on the office. Journal of business and office education, 1(1), 25-30.

Perrault, H. (2004). Business educators can take a leadership role in character education. Business education forum, $59(1), 23-24$.

Rousa, M. (2014). Soft skills. Retrieved $21^{\text {st }}$ April, 2015 from http://searchcio.techtarget: com/definition/soft-skill

Turner, L. (2005). 2o Technology skills every educator. Retrieved from http://theJournal.com/articles/2005/06/01/20-tech 